\title{
Are Bank Employees Psychologically and Structurally Empowered? an Assessment from the Indian Banking Sector
}

\author{
C. Arathy ${ }^{1} \cdot$ A. V. Biju' ${ }^{10}$
}

Accepted: 19 October 2021 / Published online: 17 November 2021

(C) The Author(s), under exclusive licence to Springer Science+Business Media, LLC, part of Springer Nature 2021

\begin{abstract}
The main purpose of our research is to seek insight into the antecedents of employee empowerment at both organizational and individual levels. We also address the outcomes of empowerment at the individual level. Subsequently, the research discusses the mediation effect of psychological empowerment on structural empowerment and its outcome as job satisfaction. A total of 400 samples were collected from the employees of public and private sector banks in India using an online questionnaire, during the Covid-19 pandemic period. To test the hypotheses, Confirmatory factor analysis (CFA) and path analysis were used. The study proved that the antecedents such as psychological and structural empowerment have a positive and significant effect on job satisfaction, while psychological empowerment partially mediates between structural empowerment and job satisfaction. This research attempts an integrative approach as suggested by the Social Cognitive Theory for predicting empowerment. We have used unidimensional constructs of psychological empowerment, structural empowerment, and job satisfaction in the Indian banking sector. This study contributes to both theory and practice by providing insights into the benefits of public and private sector bank employees which is gained through the implementation of empowerment policies during the Covid-19 period.
\end{abstract}

Keywords Public and private sector banks · Empowerment - Psychological empowerment · Structural empowerment $\cdot$ Job satisfaction $\cdot$ Covid-19

JEL Classification $\mathrm{G} 21 \cdot \mathrm{M} 10 \cdot \mathrm{J} 28$

\section{Introduction}

The concept of employee empowerment is developed in correspondence with the development and promotion of human resources of the organizations (Turban et al., 2003). Organizations are implementing several empowerment initiatives to motivate workers to perform beyond their formal job requirements and to engage in extra-role or citizenship behaviors

A. V. Biju

bijuav@keralauniversity.ac.in

1 Department of Commerce, School of Business Management \& Legal Studies, University of Kerala, Kerala, India 
(Park, 2017). Empowerment is the process of enhancing the capacity of individuals or groups to make choices and to transform those choices into desired actions and outcomes (Alsop et al., 2006). Empowerment provides a win-win situation for the organization, customers, and employees. The organization benefits from satisfied customers through competent, empowered employees. Empowerment aims to shift authority from top to bottom and switch the employees' capability into performance with their qualities and insight (Zimmerman, 1990). Empowerment is a multidimensional aspect consisting of psychological and structural empowerment. Structural empowerment is a state in the organization that influences employees' work-related behavior, allocation, and delegation of authority among managers and employees (Kanter, 1983; Conger \& Kanungo, 1988). Psychological empowerment is a set of motivational cognitions shaped by the work environment and it reflects the active orientation of an individual (Spreitzer, 1995). Job satisfaction is one of the major anticipated outcomes of empowerment (Spreitzer et al., 1997). In the words of Locke (1976), job satisfaction is a pleasurable or positive emotional state resulting from the appraisal of one's job or job experience.

The banking sector is suffering from a high degree of employee attrition rate (Branham, 2005; Nelson, 2007; Letchumanan et al., 2017). We can read from the past literature that banking sector employees are facing a high level of stress (Chen \& Lien, 2008; George \& K.A., 2015; Chaudhary \& Lodhwal, 2017). The reasons are lack of job autonomy, role conflict, long working hours, organizational culture, improper reward system, and lack of management support to employees (Ali et al., 2013). Thus the banking sector employees adopt new get-by tactics for sustaining a good physical and mental state to increase productivity (Lopes \& Kachalia, 2016). The employees of the banking sector are less satisfied and empowered than employees of other sectors (Kellev, 1990) due to the stress and lack of employee orientation.

For every organization, the workforce is the key success factor (Indermun \& Bayat, 2013). The performance of the banking sector is more closely linked to the economy than perhaps that of any other sector (Limbore, 2014). Bank employees have been given more autonomy to participate in the decision-making process (Chahal et al., 2013). The impact of Covid-19 on the banking sector has led to a severe fall in the demand for products, low incomes, and production shutdowns, all of which have adversely affected the business of banks. The situation has been worsened by staff shortages, inadequate digital maturity, and pressure on the existing infrastructure, leading the banks to struggle in order to stay profitable (Perwej, 2020). In responding to the pandemic, banks should be ready to adopt new organizational behaviors and change their business models and strategies. Empowerment is an important strategy to consider when dealing with the great pressures of the continuously changing world of work (Stander \& Rothmann, 2010).

Presently, organizations are experiencing unprecedented workforce disruption globally due to the pandemic situation. Job satisfaction is essential for the efficient implementation of empowerment by adapting modern corporate culture, which supports employee empowerment (Reidhead, 2020). There is an imperative need to assess the effects of empowerment on the job satisfaction of banking sector employees. If the employees are satisfied with their jobs, they will volunteer to help others and conduct their duties very well (Hamidizadeh et al., 2012). If the banking sector is enhances the empowerment of employees, whether psychologically or structurally, it will enhance job satisfaction. Therefore, the present study is a novel approach to investigating the effects of psychological and structural empowerment on the job satisfaction of bank employees using unidimensional constructs during the pandemic situation. Also, examined is the mediation effect of psychological empowerment on structural empowerment and job satisfaction. 


\section{Literature Review \& Development of Hypotheses}

\section{Dimensions of Employee Empowerment}

The previous literature has precisely recognized two different dimensions of empowerment, structural or relational empowerment, and psychological or motivational empowerment (Maynard et al., 2012; Rhee et al., 2017; Eylon \& Bamberger, 2000; Greasley et al., 2008; Mathieu et al., 2006). Employee empowerment changes the attitude and behavior of employees and also leads to the increase in job satisfaction and organizational commitment. The behavior changes from the empowerment will increase the employees' self-confidence, self-esteem, skill, and knowledge (Arthur, 1994; Srivastava et al., 2006; Kizilos et al., 2013; Fernandez \& Moldogaziev, 2013). We can correlate several studies of empowerment that were applied in service organizations (Conger \& Kanungo, 1988; Thomas \& Velthouse, 1990; Spreitzer, 1992, 1995; Zimmerman, 1995). Numerous studies have provided evidence of the significant association between empowerment and job satisfaction (Engström et al., 2010; Sarwar \& Khalid, 2011; Ahmad \& Oranye, 2010; Fernandez \& Moldogaziev, 2014; Bentley et al., 2012; Hanaysha \& Tahir, 2016; Kokila, 2016; Idris et al., 2018; Qing et al., 2019; Ahmad, 2020; Suriadnyana, 2020). A positive correlation exists between empowerment and job satisfaction in Chinese nurses (Ning et al., 2009). The research by Choi et al. (2016) states that the empowerment factor positively affects job satisfaction as well as acts as a mediator between transformational leadership and job satisfaction. The study by Ahmed et al. (2019) finds employee empowerment partially mediating the relationship between perceived leadership and job satisfaction.

The Social Cognitive Theory (SCT) suggests that empowerment is a dynamic and interactive process and an integrative approach will be useful to predict a complete picture of employee empowerment (Bandura, 1986). Hence, it is better to conceive structural conditions and managerial activities jointly when they are to be considered for empowerment. An integrative approach has the power to influence and reinforce the cognitive states of employee empowerment, and eventually promote positive outcomes (Mathieu et al., 2006; Menon, 2001; Robbins et al., 2002). In the same vein, the present study has adopted an integrated approach that simultaneously reflects both the structural and psychological perspectives through the understanding of the processes and manifestations of employee empowerment. The existing literature has proved the effects of psychological or structural empowerment and that its dimensions are prevalent on job satisfaction. The study is pertinent because there is a deficiency of academic work on the influence of a combined effect of both psychological and structural empowerment on a unidimensional construct of job satisfaction in the Indian banking sector.

\section{Influence of Structural Empowerment on the Job Satisfaction of Bank Employees}

Many empowerment programs fail because they focus on power without redistributing information, knowledge, and rewards. Bowen and Lawler (1992) proposed that the effective use of empowerment needs the managers to share with their employees four organizational ingredients: information about the organization 's performance, rewards based on the organization's performance, knowledge that enables employees to understand and contribute to organizational performance, and power to make decisions that influence organizational direction and performance. Our research used seven dimensions of structural 
empowerment adapted from various scales because a single scale suitable for this research was not found. These dimensions include information and communication, reward system, skills \& knowledge, decision making (Bowen \& Lawler, 1992; Spreitzer, 1995), leadership, self-esteem (Spreitzer, 1995), and role clarity (Sawyer, 1992).

Structural empowerment elements are allowed to take proper action through a set of structures, policies, and practices in the organization (Seibert et al., 2011). The structural empowerment dimensions such as access to information and reward systems have a positive impact on job satisfaction (Abadi \& Chegini, 2013). It has been proved from a study among Filipino and American registered nurses that an increase in structural empowerment level provides a positive push to increase job satisfaction and organizational commitment (Vacharakiat, 2008). Structural empowerment consists of several dimensions: employees' discretion (Rafiq \& Ahmed, 1998; Bowen \& Lawler, 1992), information sharing, knowledge and resources, responsibility, autonomy, accountability, and rewards (Bowen \& Lawler, 1992; Randolph \& Sashkin, 2002; Eylon \& Bamberger, 2000; Rafiq \& Ahmed, 1998; Eylon \& Au, 1999; Seibert et al., 2004). Structural empowerment is the significant predictor of job satisfaction ( Al-Ababneh et al., 2017; Wong \& Laschinger, 2013; Abadi \& Chegini, 2013; Pelit et al., 2011; Gazzoli et al., 2010; Lautizi et al., 2009; Patah et al., 2009; Dickson \& Lorenz, 2009; Wang \& Lee, 2009; Hechanova et al., 2006; Hancer \& George, 2003; Spreitzer, 1996; Fulford \& Enz, 1995). This research applies the theoretical models of structural empowerment on job satisfaction on the cross-sectional population of banking sector employees. This study developed the following hypothesis as evolved from the conceptual framework.

H1. Structural empowerment has a positive and significant influence on the job satisfaction of banking sector employees.

\section{Influence of Psychological Empowerment on the Job Satisfaction of Bank Employees}

The psychological empowerment aspect was introduced by Conger and Kanungo (1988) in connection with the concept of self-efficacy (Bandura, 1977) and increased intrinsic task motivation (Thomas \& Velthouse, 1990). This study used Spreitzer's (1995) psychological empowerment scale for the assessment of psychological empowerment of bank employees. This particular scale is comprised of "meaning, competence, self-determination, and impact". The term "meaning" denotes the congruence between the requirements of one's job role and one's own beliefs and values (Spreitzer, 1995; Brief \& Nord, 1990). "Competence" is the ability of an individual to perform his/her job activities with the needed knowledge and skill (Gist, 1987). "Self-determination" is a choice or freedom in initiating and controlling one's actions (Deci et al., 1989). The "impact" is the degree to which an individual can influence strategic, administrative, or operating outcomes in the work (Ashforth, 1989).

Psychological empowerment has a positive and significant impact on job satisfaction of employees (Raza et al., 2015; George, 2013; Kazlauskaitè et al., 2009; Laschinger et al., 2007; Hechanova et al., 2006; Laschinger et al., 2002; Casey et al., 2010; Laschinger et al., 2004; Quin \& Spreitzer, 1997) through employee engagement (Alagarsamy et al., 2020). The research confirms that the self-determination and competence dimension of psychological empowerment have a positive impact on job satisfaction (Abadi $\&$ Chegini, 2013). The employees with a high level of empowerment in turn have a high level 
of job satisfaction and therefore, it is recommended that the implementation of psychological empowerment should be continued for the improvement of the organization's performance (Saif \& Saleh, 2013). All three dimensions of psychological empowermentmeaning, choice, and impact-are the significant predictors of job satisfaction (Wang \& Lee, 2009). Psychological empowerment dimensions such as meaningfulness, competence, and influence have significant influence on overall job satisfaction (Patah et al., 2009). The empowerment dimensions of meaning, competence, self-determination, and impact have a positive and significant relationship with job satisfaction (Rana \& Singh, 2016). These theoretical underpinnings have led to the development of the following hypothesis.

H2. Psychological empowerment has a positive and significant influence on the job satisfaction of banking sector employees.

Psychological empowerment is a representation of how employees react to structural empowerment situations while structural empowerment is an insight into the existence or nonexistence of empowering situations in the workplace (Laschinger et al., 2001). In the same vein, structural empowerment emerged as the significant predictor of psychological empowerment (Laschinger et al., 2004; Ghani et al., 2009; Perkins, 2006; Echebiri et al., 2020). Therefore, the following hypothesis has been developed.

H2a. Structural empowerment has a positive and significant influence on the psychological empowerment of banking sector employees.

Many of the earlier studies supported the thought that psychological empowerment mediates between structural empowerment and various work outcomes (Kundu et al., 2019; Rhee et al., 2017; Amundsen \& Martinsen, 2015; Kroga \& Govender, 2015; Wagner et al., 2010; Seibert et al., 2011; Knol \& Van linge, 2009; Carless, 2004; Laschinger et al., 2001). Similarly, psychological empowerment acts as a mediating variable between structural empowerment and job satisfaction (Pelit et al., 2011; Huang \& Wang, 2006; Laschinger, 2008; Lee, 2003). Psychological empowerment mediates the relationship between transformational leadership and career satisfaction (Joo \& Lim, 2013), job satisfaction (Aydogmus et al., 2018), task performance (Guerrero et al., 2018), organizational citizenship behavior, and turnover intention (Saira et al., 2021). Psychological empowerment provides a more efficient empirical approach to evaluate the effectiveness of employee empowerment (Menon, 2001). Studies related to the service sector employees on the relationship between psychological empowerment and its consequences are rare (Jha, 2011). Based on this conceptual development, we framed a hypothesis as follows.

$\mathrm{H} 2 \mathrm{~b}$. Psychological empowerment positively mediates the relationship between structural empowerment and job satisfaction.

\section{Conceptual Framework}

Figure 1 symbolizes the interrelationship between psychological and structural empowerment evolved from the theoretical underpinnings of empowerment. It shows the direct and indirect effect on the outcome variable job satisfaction of the employees in the banking sector. Our research strongly believes that employee empowerment can be achieved through psychological and structural empowerment. Structural empowerment acts as an 


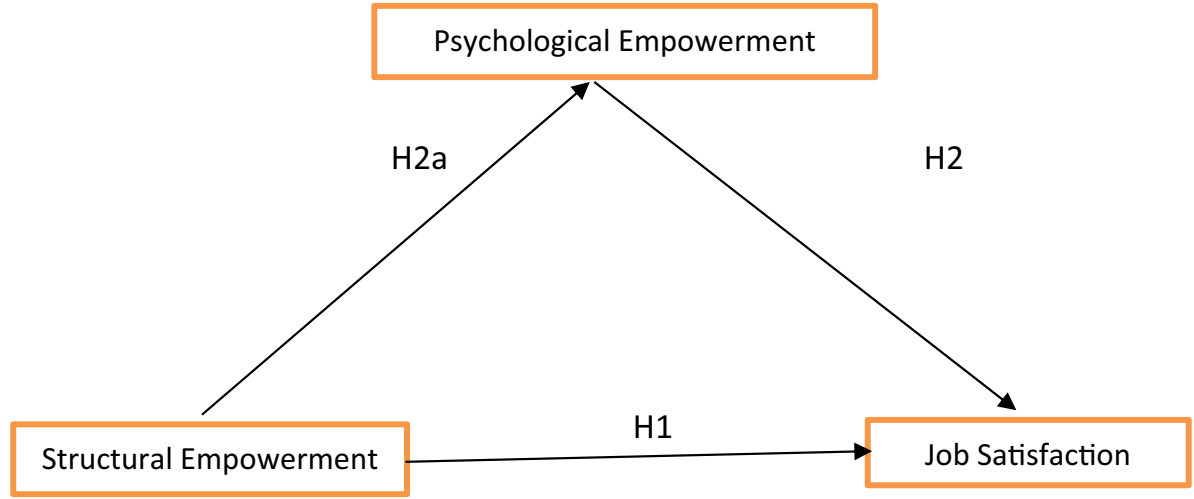

Fig. 1 Conceptual framework. The proposed research model was adapted from the theoretical context of empowerment. Structural and psychological empowerment are the antecedents of employee empowerment and job satisfaction as a consequent variable. Structural empowerment has a direct and indirect influence on the outcome variable job satisfaction through the mediating variable psychological empowerment

independent variable, psychological empowerment as a mediating variable, and job satisfaction as a dependent variable. Firstly, the direct relationship between structural empowerment and job satisfaction was empirically tested. After that, we tested the effect of structural empowerment on psychological empowerment. We also undertook the testing of the mediation effect of psychological empowerment on structural empowerment and job satisfaction.

\section{Research Design}

\section{Data Collection}

The population of the research is finite with 58,506 full-time employees including officers and clerks in the commercial banks in Kerala (SLBC, 2015) ${ }^{1}$. Yamane formula has been applied to determine the sample size of bank employees with a $95 \%$ confidence level and e(error) $=0.5$ (Yamane, 1967). As suggested by Easton and McColl (1997), we used a multi-stage random sampling method for surveying employees from public and private sector banks. In the first stage, 12 banks from the public sector and 11 from the private sector were selected based on domiciles. In the second stage, 36 branches from the public and 33 from the private sector were selected. In the third stage, 200 employees each from public and private banks were selected randomly. This included 106 officers and 94 clerks from public sector banks and 108 officers and 92 clerks from private sector banks. A total of 465 questionnaires were distributed among the bank employees and only 426 were returned duly filled. The data of 400 questionnaires were found useful with a response rate of $86 \%$.

\footnotetext{
1 State Level Bankers Committee 2015, SLBC is an inter-institutional forum at state level ensuring coordination between government and banks on matters pertaining to banking development (www.slbckerala. com).
} 
The data were collected during the pandemic period from August to October 2020 using online mode.

\section{Measures}

All items were measured using a five-point Likert scale ranging from 1 to 5 , in which respondents denoted their agreement-5 (Strongly agree), 4 (Agree), 3 (Neutral), 2 (Disagree), and 1 (Strongly disagree) — with positively and negatively worded statements (Likert, 1932). The scales used to measure the three constructs such as psychological empowerment, structural empowerment, and job satisfaction are reported in Table 1.

Cronbach's alpha value for the psychological empowerment scale is 0.863 , which shows good reliability as per the rule of thumb. The alpha value of the structural empowerment scale is 0.951 and the job satisfaction scale is 0.90 , which means the alpha is excellent (George \& Mallery, 2003).

The Composite Reliability (CR) of all the constructs ranges from 0.80 to 0.91 , which is above the cut-off value of 0.7 (Hair et al., 2009). AVE (Average Variance Extracted) of all constructs shown are above 0.50 and confirms the convergent validity of constructs (Fornell, C., \& Larcker, 1981; Hair et al., 2010). The reliability and validity of all the items in the construct used for the present study are demonstrated in Table 2)

\section{Results \& Discussion}

\section{Descriptive Statistics and Factor Loadings of Construct}

The result of descriptive statistics and factor loadings of the constructs used in the study are reported in Table 3. The employees of the banking sector have a high level of psychological empowerment, structural empowerment, and job satisfaction with mean scores of 3.90, 3.97, and 3.92, respectively. The factor loading score (standardized loading) above 0.30 is significant for the sample size of more than 350 respondents (Hair et al., 2018). Since our sample size is 400 and all standardized factor loadings range from 0.534 to 0.893 , they are significant by the guidelines for identifying significant factor loadings based on sample size (Hair et al., 2018).

\section{Statistical Methods}

The analysis of data was done in two phases. The first phase is the measurement (inner) model which examines the correlation among indicators of latent variables of psychological empowerment, structural empowerment, and job satisfaction. The second phase is structural (outer) models that test the fitness of all the constructs (dependent variable job satisfaction, independent variable structural empowerment, and psychological empowerment as the mediating variable) with the help of path analysis as suggested by Hoyle (1995), Kline (2010), Hoyle (2011), Kline (2005), and Hair et al. (2006a, b). Confirmatory factor analysis (CFA) and path analysis were used to test the measurements and structural models respectively using Analysis of Moment Structures (AMOS) version 20.0 software. The parameters were estimated using Maximum likelihood (ML) estimation with a sample size of 400. The absolute, incremental and parsimonious model fit indices, namely, Chi-square/df $<5.00$ (Hair et al., 1998), Comparative Fit Index (CFI) $>0.90$ (Hooper et al., 2008), Goodness of fit index (GFI) $>0.90$, 


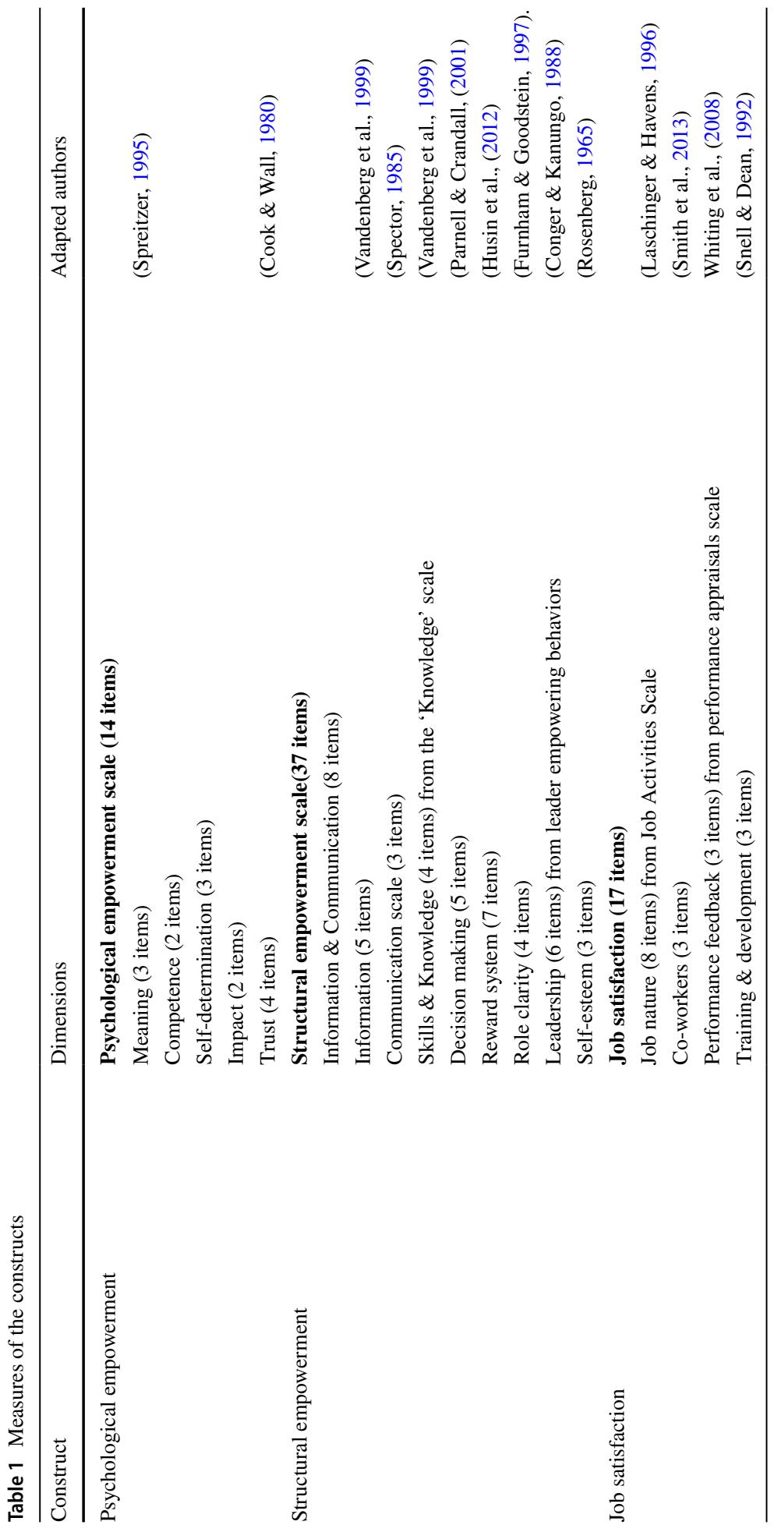


Table 2 Reliability and validity of the constructs

\begin{tabular}{llll}
\hline Constructs & $\begin{array}{l}\text { Cronbach's } \\
\text { Alpha }\end{array}$ & AVE & CR \\
\hline Psychological empowerment & 0.86 & 0.52 & 0.82 \\
Structural empowerment & 0.95 & 0.59 & 0.91 \\
Job satisfaction & 0.89 & 0.51 & 0.80
\end{tabular}

AVE - Average Variance Extracted $>0.50$ shows convergent validity; CR - Composite Reliability $>0.70$

Table 3 Descriptive statistics and factor loadings of constructs

\begin{tabular}{llllll}
\hline Constructs & Mean & SD & Unstandardized & SE & Standardized \\
\hline Psychological empowerment & 3.9 & & & & \\
Meaning & 3.81 & 0.69 & 0.67 & 0.07 & 0.64 \\
Competence & 4.34 & 0.58 & 0.55 & 0.06 & 0.61 \\
Self-determination & 3.71 & 0.85 & 1 & - & 0.77 \\
Impact & 3.66 & 0.84 & 0.67 & 0.08 & 0.53 \\
Trust & 3.98 & 0.61 & 0.60 & 0.06 & 0.65 \\
Structural empowerment & 3.97 & & & & \\
Information \& communication & 4.04 & 0.59 & 0.99 & 0.05 & 0.89 \\
Skills \& knowledge & 4.1 & 0.6 & 0.79 & 0.05 & 0.71 \\
Decision making & 3.84 & 0.61 & 0.94 & 0.05 & 0.83 \\
Role clarity & 3.95 & 0.59 & 0.82 & 0.04 & 0.74 \\
Leadership & 3.92 & 0.55 & 0.66 & 0.05 & 0.64 \\
Self-esteem & 4.03 & 0.71 & 0.99 & 0.07 & 0.74 \\
Reward system & 3.89 & 0.68 & 1 & - & 0.77 \\
Job satisfaction & 3.92 & & & & \\
Job nature & 3.84 & 0.58 & 0.77 & 0.06 & 0.73 \\
Co-workers & 4.07 & 0.67 & 0.86 & 0.07 & 0.70 \\
Performance feedback & 3.98 & 0.64 & 0.83 & 0.07 & 0.71 \\
Training \& development & 3.78 & 0.8 & 1 & - & 0.68 \\
\hline
\end{tabular}

SD - Standard deviation; SE - Standard error

Normed Fit Index (NFI) > 0.90, Tucker Lewis Index (TLI) > 0.90 (Hu \& Bentler, 1999), Adjusted Goodness of Fit Index (AGFI) $>0.90$, Root Mean Square Residual (RMR) $<0.08$ and Root Mean Square of Error Approximation (RMSEA) < 0.08 (Hair et al., 2006a, b) were chosen to evaluate the goodness of model fit. As the data is cross-sectional, Harman's single factor test was performed to determine common method bias. The result indicates that a single factor explains $38.45 \%$ variance, which is less than $50 \%$. So there are no common method biases in this data (Aguirre-Urreta \& Hu, 2019).

\section{Measurement Model}

The measurement model is used to check the reliability and validity of the relationship between latent variables and indicator variables through confirmatory analysis (Hair et al., 
Table 4 Discriminant validity

\begin{tabular}{llll}
\hline Construct & $\begin{array}{l}\text { Psychological empower- } \\
\text { ment }\end{array}$ & $\begin{array}{l}\text { Structural empower- } \\
\text { ment }\end{array}$ & Job satisfaction \\
\hline Psychological empowerment & 0.72 & - & - \\
Structural empowerment & 0.22 & 0.76 & - \\
Job satisfaction & 0.13 & 0.21 & 0.71 \\
\hline
\end{tabular}

Discriminant validity - Square roots of $\operatorname{AVE}(0.72,0.76$ and 0.71$)>$ correlations between the latent variables psychological empowerment, structural empowerment and job satisfaction (0.22, 0.21 and 0.13); AVE - Average Variance Extracted

2020; Doloi et al., 2011). This model has 16 items with three latent variables. All the indices of this model fell within the threshold limit, indicates a good model fit $(\chi 2 / d f=1.876$, $G F I=0.998, A G F I=0.991, N F I=0.993, T L I=0.975, C F I=0.990 ; R M S E A=0.034 ; R M R$ $=0.018$ ). Here we have used a reflective measurement model. Hence, we should check the three main criteria that are necessary to be followed. These criteria include internal consistency, convergent validity, and discriminant validity (Hair et al., 2017). After confirming the model fit of the measurement model, the next step is to calculate Composite Reliability (CR) to measure internal consistency. The reliability values of all the constructs are above 0.7, which indicate good internal consistency (Hair et al., 2009). The next criterion to assess is the validity of the measurement model using convergent and divergent validity. Convergent validity measures a particular construction that is capable of measuring what is expected to be measured (Hair et al., 2010). The Average Variance Extracted (AVE) of all three latent constructs are above 0.50 , which confirm that convergent validity is satisfied (Acock, 2013). Items for each construct together elucidate more than $50 \%$ variance of the target constructs (Bagozzi \& Yi, 1988; Hair et al., 2014). Discriminant validity determines whether the construct is different from other constructs (Hair et al., 2010). Table 4 reports the result of the measurement model, which is fit as per the above-discussed criteria. If the square root of AVE on the diagonal should be higher than the correlations between the latent variables, it is treated as discriminant validity (Fornell \& Larcker, 1981). The measurement model of our study met all the criteria regarding reliability, validity, and goodness of model fit. Hence, it is obvious that this model is suitable for further analysis of the structure model.

\section{Structural Model}

The structural model reports the path strength and relationship among the latent variables. Figure 2 exhibits the path analysis of the structural model to test the hypothesized model. It is concerned with the relationship among three latent variables, namely, psychological empowerment, structural empowerment, and job satisfaction. Table 5 reports that the model is a good fit because all the values are within the acceptable level. Therefore, it can be used to test the hypotheses of the structural model $(\chi 2 / d f=1.529, G F I=0.942$, $A G F I=0.953, N F I=0.988, T L I=0.903, C F I=0.998 ; R M S E A=0.031 ; R M R=0.014)$. We did a multicollinearity check using the Variance Inflation Factors (VIF) to identify the reliability for path analysis in the Structural Model. Table 5 shows that all the values of VIF are below 5, which means that there are no multicollinearity issues (Hair et al., 2018), and the model is suitable for conducting path analysis. 


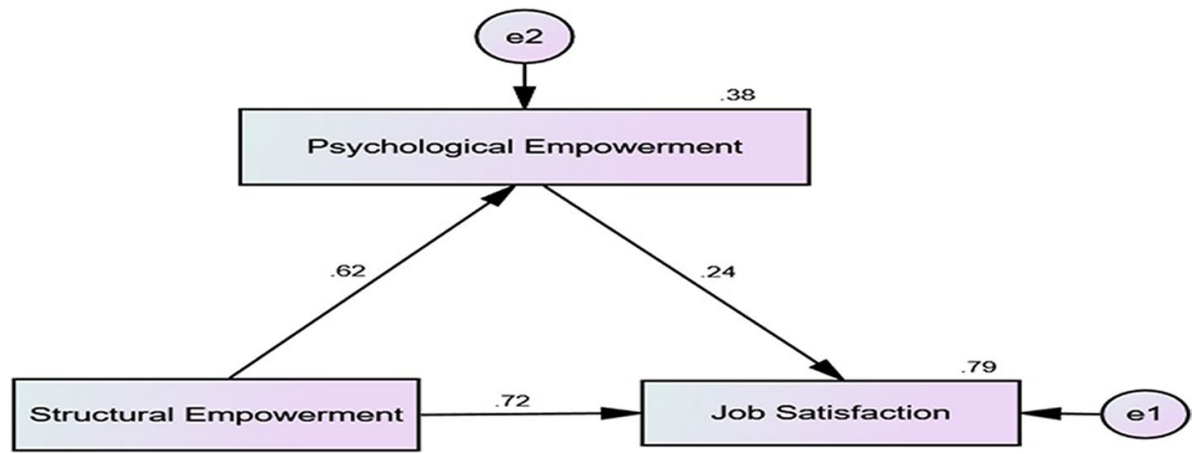

Fig. 2 Structural model. Note: Mediation effect of psychological empowerment on structural empowerment and job satisfaction using path analysis (Job satisfaction <--- Psychological empowerment <--- Structural empowerment). Structural empowerment - independent variable; Psychological empowerment - mediating variable; Job satisfaction - dependent variable

Table 5 Summary of Model-fit indices for Structural model

\begin{tabular}{|c|c|c|c|c|c|c|c|c|}
\hline \multirow[t]{2}{*}{ Model Fit } & $\chi^{2 / d f}$ & GFI & AGFI & NFI & TLI & CFI & RMR & RMSEA \\
\hline & 1.53 & 0.942 & 0.953 & 0.988 & 0.903 & 0.998 & 0.031 & 0.014 \\
\hline
\end{tabular}

$\chi^{2 / \mathrm{df}}-$ Chi-square/degrees of freedom $<5.00 ;$ CFI - Comparative Fit Index $>0.90$; GFI - Goodness of Fit Index > 0.90; NFI - Normed Fit Index > 0.90; TLI - Tucker Lewis Index > 0.90; AGFI - Adjusted Goodness of Fit Index > 0.90; RMR - Root Mean Square Residual < 0.08; RMSEA - Root Mean Square of Error Approximation < 0.08 (Hair et al., 2006a, b)

Table 6 Collinearity Statistics and $\mathrm{R}$ square value of Structural model

\begin{tabular}{lll}
\hline Construct & VIF & R2 value \\
\hline Psychological empowerment & 1.70 & 0.38 \\
Structural empowerment & 1.32 & - \\
Job satisfaction & 1.69 & 0.79 \\
\hline
\end{tabular}

VIF - Variance Inflation Factor $<5$ shows no multicollinearity

$\mathrm{R}$ square value of the constructs was used to measure the model's explanatory power (Hair et al., 2014). The $\mathrm{R}$ square value of psychological empowerment is 0.383 and job satisfaction is 0.793 (see Table 6). It infers that the $\mathrm{R}$ square value is greater than 0.26 proposed by Cohen (1988), which shows the high explanatory power of the present model. It implies that structural empowerment explains $38.3 \%$ variation in psychological empowerment and $79.3 \%$ variation in job satisfaction. 
Table 7 Summary of hypotheses testing

\begin{tabular}{|c|c|c|c|c|c|}
\hline Hypothesis & & Structural relationship & $\begin{array}{l}\text { Standardized } \\
\text { regression } \\
\text { weight }\end{array}$ & $\mathrm{p}$-value & Result \\
\hline & Total effect & JS<---SE & 0.87 & $<0.001 * * *$ & \\
\hline H1 & Direct effect & JS<---SE & 0.72 & $<0.02 * *$ & Supported \\
\hline $\mathrm{H} 2$ & & JS<---PE & 0.21 & $<0.001 * * *$ & Supported \\
\hline $\mathrm{H} 2 \mathrm{a}$ & & $\mathrm{PE}<---\mathrm{SE}$ & 0.61 & $<0.001 * * *$ & Supported \\
\hline $\mathrm{H} 2 \mathrm{~b}$ & Indirect effect & $\mathrm{JS}<---\mathrm{PE}<---\mathrm{SE}$ & 0.14 & $<0.001 * * *$ & Partially Supported \\
\hline
\end{tabular}

Structural relationship - relationship of independent variable on dependent variable; SE - Structural Empowerment; PE - Psychological Empowerment; JS - Job Satisfaction; p value $<0.001 * * *$ significant at $1 \%$ level, p value $<0.02 * *$ significant @ $5 \%$ level

\section{Testing of Hypotheses}

\section{Testing of the Total Effect}

The total effect is the sum of direct and indirect effects. The result shows that structural empowerment positively and significantly influences job satisfaction (Standardized Beta $=0.87 ; \mathrm{p}<0.001)$, reports in Table 7 .

\section{Testing of Direct Effect}

Direct effect denotes the relationship between independent and dependent variables without adding a mediating variable. Table 6 reports the direct influence of structural empowerment on job satisfaction and structural empowerment to psychological empowerment. The result indicates that Standardized Beta $=0.72 ; \mathrm{p}<0.01$ for structural empowerment to job satisfaction. Also, Standardized Beta $=0.61 ; p<0.001$ for the relationship between structural empowerment and psychological empowerment. Therefore, the results support both $\mathrm{H} 1$ and $\mathrm{H} 2 \mathrm{a}$. The theories evolved after testing hypotheses are, a). Structural empowerment has a positive and significant influence on job satisfaction of bank employees and b). Structural empowerment has a positive and significant influence on the psychological empowerment of bank employees. Moreover, the analysis also supports $\mathrm{H} 2$, that psychological empowerment has a vital influence on the job satisfaction of bank employees (Standardized Beta $=0.24 ; \mathrm{p}<0.001$ ).

\section{Testing of the Indirect Effect}

Indirect effect denotes the relationship between independent and dependent variables mediated by other variables. Here, the mediating effect of structural empowerment on job satisfaction through psychological empowerment has been assessed (JS<---PE $<-$ --SE). We used bootstrapping method with subsamples of 5000 to test the mediation effect (Preacher \& Hayes, 2004) and the significance level of path models (Henseler et al., 2009). We can see that the direct influence of structural empowerment on job satisfaction has been reduced to a non-trivial amount in the presence of mediating variable 
psychological empowerment (Standardized Beta $=0.14 ; \mathrm{p}<0.001)$. Still, it remained significant ( see Table 6).

To explain mediation analysis (Baron \& Kenny, 1986), four criteria were used. Firstly, the independent variable (structural empowerment) is significantly and positively related to dependent variables (job satisfaction). Secondly, the independent variable (structural empowerment) is significantly and positively related to mediator variables (psychological empowerment). Thirdly, mediator variables (psychological empowerment) are significantly and positively related to dependent variables (job satisfaction). Lastly, the direct relationship between independent variables (structural empowerment) and dependent variables (job satisfaction) is reduced, but significant in the presence of a mediator. In the presence of a mediator, if the direct relationship between independent variables and the dependent variable is reduced and shows insignificant effect, then full mediation can be claimed. In this case, the direct relationship between structural empowerment and job satisfaction is reduced, but shows a significant effect. Hence, partial mediation is supported (Baron \& Kenny, 1986). Therefore, the result partially supports H2b, that psychological empowerment partially mediates the relationship between structural empowerment and job satisfaction of banking sector employees.

\section{Discussion}

This study is mainly focused on analysing the effect of employee empowerment in terms of psychological and structural empowerment on job satisfaction. The research also examined the mediation mechanism of psychological empowerment towards structural empowerment and job satisfaction of public and private bank employees. The findings validate and support the previous studies in the matter of psychological empowerment having a positive and significant effect on job satisfaction (Esmaeilifar et al., 2020; Aydogmus et al., 2018; Jordan et al., 2017; Raza et al., 2015). Structural empowerment has a positive and significant effect on the job satisfaction of employees, which is also consistent with previous studies. Hence, it is obvious that an increase in psychological and structural empowerment significantly increases the job satisfaction of bank employees. The result of the study supports the previous studies in the theory that empowered employees are more likely to be satisfied with their job compared with less empowered employees (Kokila, 2016, Bogler $\&$ Nir, 2012, and Pelit et al., 2011). Furthermore, the result also exhibits that structural empowerment is significantly related to psychological empowerment (Echebiri et al., 2020; Ghani et al., 2009). Finally, the study has successfully proved the mediation effect of psychological empowerment on structural empowerment and job satisfaction and the result validates the theory that psychological empowerment acts as a partial mediator (Pelit et al., 2011; Laschinger, 2008).

\section{Theoretical Contributions}

For researchers, the study provides an insight into the existing theoretical knowledge by examining the direct and indirect effects of structural empowerment on job satisfaction through psychological empowerment. Our findings have confirmed that an integrative approach is a better tactic to understand the concept of employee empowerment, as structural empowerment emerges as a significant predictor of psychological empowerment. The partial mediation of 
psychological empowerment is also evidenced to enhance job satisfaction. Hence, an integrative approach is a much better choice than a single one as both approaches are congruent to each other. Moreover, the structural and psychological empowerments act as a catalyst during the pandemic situation for the banking sector to withstand the wave of change ahead.

In the present academic literature, only a few empirical studies are related to the integrative approach of employee empowerment. As a part of the change in business environment and increasing global competition, the concept of employee empowerment has gained the focus of managers because organizations with empowered, motivated, committed, and skilled employees can better adapt themselves to change. The banking sector is an integral part of modern society and needs to be opened even in the extreme situation of the Covid-19 pandemic period. The shift system has been adopted because all the employees cannot work together during this period. Therefore, all levels of employees will have to take responsibility for customer service for the growth of the entire banking sector. In this context, the internal and external empowerment is a blessing as it gives authority to employees to deal with daily job activities as well as to manage their work and share their thoughts openly to improve the organizational practices (Baird \& Wang, 2010; Greasley et al., 2005). This study provides a new pointer for the banking sector on how to overcome the uncertainty that has emerged in the pandemic situation.

\section{Managerial Implications}

Globally, Covid-19 having the greatest impact on the service sector, it is imperative for the industry to look for ways to not only attract but also retain top talent (Murray \& Holmes, 2021). The practical implication for Indian bank managers, with the insights of our research, suggest that the psychological aspect needs to be improved because it is currently less influential as compared to the structural facet. Research results show that the empowering conditions prevailing in banks are effective, but only to an extent. There are situations in which the employees have not been able to perceive the empowerment properly. This might be because the influence of psychological empowerment on job satisfaction is low. To improve the level of psychological empowerment, the management should encourage employees to be intellectually competent and confident enough to make decisions affecting their work. Also, we suggest that the employees should improve their influence on the organization. In addition to this, the employees need to increase their self-confidence in providing unique services to customers. Another suggestion is that the performance of the organization should be communicated to the employees. Furthermore, banks need to provide training to encourage employees to produce more fruitful services in the future. The overall result of this research implies that the banking sector practices employee empowerment for increases in job satisfaction. In short, this study shed some light on the theoretical context of employee empowerment, which will hopefully give researchers and academicians a better understanding of the same. Our findings may also give practical wisdom to the policymakers of the banking sector.

\section{Limitations and Future Research Implications}

Despite all benefits, this study also goes through some limitations. Firstly, we studied only the individual dimension of employee empowerment. Secondly, we addressed the effects of empowerment on the employees only. However, "empowerment" benefits organizations, employees, and customers alike (Singh \& Singh, 2019; Greasley et al., 2005). Thirdly, this 
study omits the effects of demographic variables like gender, age, income, etc., which can be included in future research studies. Fourthly, the study represents the overall result of public and private sector banks. A comparative study can be conducted to find out the status of empowerment in each sector and determine which sector will gain more through empowerment. To recapitulate, empowerment is hailed as a management technique that can be applied universally to all organizations. Hence, there is a wide scope for further research on empowerment in manufacturing and service sectors with different outcomes at organizational, individual, and customer levels. Future research could be conducted on the influence of empowerment on organizational commitment, organizational effectiveness, customer satisfaction, performance, and retention of employees by the academic and industry community.

\section{Conclusions}

This study tries to establish the influence of psychological and structural empowerment in determining job satisfaction and the mediating role of psychological empowerment between structural empowerment and job satisfaction. Our research finds that psychological and structural empowerment play a major role in improving job satisfaction and that psychological empowerment acts as a partial mediator. Also, the bank employees perceived a high level of psychological empowerment, structural empowerment, and job satisfaction. They have adequate freedom of choice to make decisions regarding their work matters without the intervention of anyone else. This increases the self-confidence, creativity, innovation, and competence of the employees and as a result, their performance and satisfaction were improved. To sum up, psychological and structural empowerment positively and significantly influence the job satisfaction of bank employees. Since employees in the banking sector are empowered, it reflects in their practical ability to successfully deal with stressful situations that have arisen in the pandemic situation, in making their own decisions without needing permission from higher authorities, and in serving their customers in better ways. Hence, it is pertinent to have policy decisions to enhance the empowerment level of the banking sector employees to improve job satisfaction so that it, in turn, improves their commitment towards the job.

Supplementary Information The online version contains supplementary material available at https://doi. org/10.1007/s10672-021-09393-z.

Acknowledgements We acknowledge the contribution of the chief editor Professor Jack Howard for the timely suggestions and advises to make this manuscript to a well refined manner. We also acknowledge other referees who provide us a significant comments and suggestions for the further refinement of the paper. We acknowledge the respondents, the bank employee's cooperation during the data collection process. We recognize our university data base for the essential data support for the development process of this manuscript.

\section{Declarations}

We hereby submit the following conditions as the compliance of ethical standards regarding the paper titled "Does the bank employees are psychologically and structurally empowered? An Empirical Assessment" submitted to the Employee Responsibilities and Rights Journal.

a. Clause of Disclosure of potential conflicts of interest:

We the authors do not have any kind of potential conflicts of interest in the process of preparation of the paper or during research.

b. Research involving Human Participants and/or Animals:

We do not harm human being or animals during the process of research. 
c. We make sure that all data and materials as well as software application or custom code support their published claims and comply with field standards.

d. Ensuring that all listed authors have approved the manuscript before submission, including the names and order of authors.

e. Managing all communication between the Journal and all co-authors, before and after publication.

f. Providing transparency on re-use of material and mention any unpublished material (for example manuscripts in press) included in the manuscript in a cover letter to the Editor.

g. Making sure disclosures, declarations, and transparency on data statements from all authors are included in the manuscript as appropriate.

\section{References}

Abadi, M. V. N. A., \& Chegini, M. G. (2013). The relationship between employees empowerment with job satisfaction in Melli Bank of Guilan Province. Oman Chapter of Arabian Journal of Business and Management Review, 2(12), 71-79. https://doi.org/10.12816/0002363.

Acock, A. C. (2013). Discovering structural equation modeling using stata. In Italian Stata Users Group Meeting. Stata Press. http://www.stata.com/meeting/italy13/abstracts/materials/it13_huber.pdf

Aguirre-Urreta, M. I., \& Hu, J. (2019). Detecting common method bias: Performance of the Harman's single-factor test. Data Base for Advances in Information Systems, 50(2), 45-70. https://doi.org/10.1145/ 3330472.3330477.

Ahmad, M. A. (2020). The mediating role of job satisfaction on the relationship between organizational support, employee empowerment and turnover intention of Jordanian auditors. International Journal of Scientific and Technology Research, 9(3).

Ahmad, N., \& Oranye, N. (2010). Empowerment, job satisfaction and organizational commitment: A comparative analysis of nurses working in Malaysia and England. Journal of Nursing Management, 18, 582-591. https://doi.org/10.1111/j.1365-2834.2010.01093.x.

Ahmed, S., Ansari, J., Khan, Y. W., \& Ramish, M. S. (2019). Are Bank employees satisfied with perceived leadership and empowerment? The Lahore Journal of Business, 7(2), 95-120.

Al-Ababneh, M., Al-Sabi, S., Al-Shakhsheer, F., \& Masadeh, M. (2017). The influence of employee empowerment on employee job satisfaction in five-star hotels in Jordan. International Business Research, 10(3), 133. https://doi.org/10.5539/ibr.v10n3p133.

Alagarsamy, S., Mehrolia, S., \& Aranha, R. H. (2020). The mediating effect of employee engagement: how employee psychological empowerment impacts the employee satisfaction? A study of Maldivian Tourism Sector. Global Business Review. https://doi.org/10.1177/0972150920915315.

Ali, T. Y., Hassan, A., Ali, T., \& Bashir Dr, R. (2013). Stress management in private banks of Pakistan. Journal of Emerging Trends in Economics and Management Sciences, 4(3), 308-320. http://sfx.cranf ield.ac.uk/cranfield?url_ver=Z39.88-2004\&rft_val_fmt=info:ofi/fmt:kev:mtx:journal\&genre=unkno wn\&sid=ProQ:ProQ\%253Aabiglobalalumni\&atitle=Stress+Management+in+Private+Banks+of+ Pakistan\&title $=$ Journal+of+Emerging+Trends+in+Economics+and+Manag .

Alsop, R., Bertelsen, M. F., \& Holland, J. (2006). Empowerment in practice: From analysis to implementation. World Bank. https://digitallibrary.un.org/record/577228.

Amundsen, S., \& Martinsen, Ã. (2015). Linking empowering leadership to job satisfaction, work effort, and creativity: The role of self-leadership and psychological empowerment. Journal of Leadership \& Organizational Studies, 22. https://doi.org/10.1177/1548051814565819.

Arthur, J. B. (1994). Effects of human resource systems on manufacturing performance and turnover. Academy of Management Journal, 37(3), 670-687. https://doi.org/10.5465/256705.

Ashforth, B. E. (1989). The experience of powerlessness in organizations. Organizational Behavior and Human Decision Processes, 43(2), 207-242. https://doi.org/10.1016/0749-5978(89)90051-4.

Aydogmus, C., Camgoz, S. M., Ergeneli, A., \& Ekmekci, O. T. (2018). Perceptions of transformational leadership and job satisfaction: The roles of personality traits and psychological empowerment. Journal of Management \& Organization, 24(1), 81-107. https://doi.org/10.1017/jmo.2016.59.

Bagozzi, R., \& Yi, Y. (1988). On the evaluation of structure equation models. Journal of the Academy of Marketing Science, 16, 74-94. https://doi.org/10.1007/BF02723327.

Baird, K., \& Wang, H. (2010). Employee empowerment: Extent of adoption and influential factors. Personnel Review, 39(5), 574-599. https://doi.org/10.1108/00483481011064154.

Bandura, A. (1977). Self-efficacy: Toward a unifying theory of behavioral change. Psychological Review, 84(2), 191-215. https://doi.org/10.1037//0033-295x.84.2.191. 
Bandura, A. (1986). Social foundations of thought and action: A social cognitive theory. In Social Learning Theory (Issue October). Prentice-Hall. http://www.esludwig.com/uploads/2/6/1/0/26105457/bandu ra_sociallearningtheory.pdf

Baron, R. M., \& Kenny, D. A. (1986). The moderator-mediator variable distinction in social psychological research. conceptual, strategic, and statistical considerations. Journal of Personality and Social Psychology, 51(6), 1173-1182. https://doi.org/10.1037/0022-3514.51.6.1173.

Bentley, K., Omer, T., \& Sharp, N. (2012). Business strategy, financial reporting irregularities, and audit effort. Contemporary Accounting Research, 30. https://doi.org/10.2139/ssrn.1705726

Bogler, R., \& Nir, A. E. (2012). The importance of teachers' perceived organizational support to job satisfaction: What's empowerment got to do with it? Journal of Educational Administration, 50(3), 287306. https://doi.org/10.1108/09578231211223310.

Bowen, D. E., \& Lawler, E. E. (1992). The empowerment of service workers: what, why, how, and when. Sloan Management Review, 33(3), 31-39.

Branham, L. (2005). The_seven_hidden_reasons_employees_leave. Amazon books. Logistics, and Informatics

Brief, A. P., \& Nord, W. R. (1990). Meanings of occupational work. In Meanings of occupational work: A collection of essays. Lexington.

Carless, S. A. (2004). Does psychological empowerment mediate the relationship between psychological climate and job satisfaction? Journal of Business and Psychology, 18(4), 405-425. https://doi.org/10. 1023/B:JOBU.0000028444.77080.c5.

Casey, M., Saunders, J., \& O’hara, T. (2010). Impact of critical social empowerment on psychological empowerment and job satisfaction in nursing and midwifery settings. Journal of Nursing Management, 18(1), 24-34. https://doi.org/10.1111/j.1365-2834.2009.01040.x.

Chahal, S., Chowdhary, B., \& Chahal, J. (2013). Job satisfaction among bank employees: an analysis of the contributing variables towards job satisfaction. International Journal of Scientific \& Technology Research, 2(8), 11-20.

Chaudhary, P., \& Lodhwal, R. K. (2017). An analytical study of organizational role stress (ORS) in employees of nationalized banks: A case of Allahabad Bank. Journal of Management Development, 36(5), 671-680. https://doi.org/10.1108/JMD-09-2015-0137.

Chen, M. F., \& Lien, G. Y. (2008). The mediating role of job stress in predicting retail banking employees' turnover intentions in Taiwan. Service Operations and Logistics and Informatics, 1, 393-398. https:// doi.org/10.1109/SOLI.2008.4686427.

Choi, S. L., Goh, C. F., Adam, M. B. H., \& Tan, O. K. (2016). Transformational leadership, empowerment, and job satisfaction: The mediating role of employee empowerment. Human Resources for Health, 14(73), 1-14. https://doi.org/10.1186/s12960-016-0171-2.

Cohen, J. (1988). Statistical power analysis for the behavioral sciences. In Statistical Power Analysis for the Behavioral Sciences (2nd ed.). Lawrence Erlbaum Associates. https://doi.org/10.4324/9780203771 587.

Conger, J. A., \& Kanungo, R. N. (1988). The empowerment process: integrating theory and practice. Academy of Management Review, 13(3), 471-482. https://doi.org/10.5465/amr.1988.4306983.

Cook, J., \& Wall, T. (1980). New work attitude measures of trust, organizational commitment and personal need non-fulfilment. Journal of Occupational Psychology, 53(1), 39-52. https://doi.org/10.1111/j. 2044-8325.1980.tb00005.x.

Deci, E. L., Connell, J. P., \& Ryan, R. M. (1989). Self-determination in a work organization. Journal of Applied Psychology, 74(4), 580-590. https://doi.org/10.1037/0021-9010.74.4.580.

Dickson, K. E., \& Lorenz, A. (2009). Psychological empowerment and job satisfaction of temporary and part-time nonstandard workers: a preliminary investigation. Journal of Behavioral and Applied Management, 10, 166-192. https://doi.org/10.21818/001c.17252.

Doloi, H., Iyer, K., \& Sawhney, A. (2011). Structural equation model for assessing impacts of contractor's performance on project success. International Journal of Project Management, 29, 687-695. https:// doi.org/10.1016/j.ijproman.2010.05.007.

Easton, V. J., \& McColl, J. H. (1997). Presenting Data. STEPS Statistics Glossary Web

Echebiri, C., Amundsen, S., \& Engen, M. (2020). Linking structural empowerment to employee-driven innovation: the mediating role of psychological empowerment. Administrative Sciences, 10(3), 42. https://doi.org/10.3390/admsci10030042.

Engström, M., Wadensten, B., \& Häggström, E. (2010). Caregivers' job satisfaction and empowerment before and after an intervention focused on caregiver empowerment. Journal of Nursing Management, 18(1), 14-23. https://doi.org/10.1111/j.1365-2834.2009.01047.x. 
Esmaeilifar, R., Iranmanesh, M., Shafiei, M. W. M., \& Hyun, S. S. (2020). Effects of low carbon waste practices on job satisfaction of site managers through job stress. Review of Managerial Science, 14(1), 115-136. https://doi.org/10.1007/s11846-018-0288-x.

Eylon, D., \& Au, K. Y. (1999). Exploring empowerment cross-cultural differences along the power distance dimension. International Journal of Intercultural Relations, 23(3), 373-385. https://doi.org/ 10.1016/S0147-1767(99)00002-4.

Eylon, D., \& Bamberger, P. (2000). Empowerment cognitions and empowerment acts: Recognizing the importance of gender. Group and Organization Management, 25(4), 354-372. https://doi.org/10. $1177 / 1059601100254003$.

Fernandez, S., \& Moldogaziev, T. (2013). Employee empowerment, employee attitudes, and performance: testing a causal model. Public Administration Review, 73(3), 490-506. https://doi.org/10. 1111/puar.12049.

Fernandez, S., \& Moldogaziev, T. (2014). Employee empowerment and job satisfaction in the U.S. Federal Bureaucracy: a self-determination theory perspective. The American Review of Public Administration, 45(4), 375-401. https://doi.org/10.1177/0275074013507478.

Fornell, C., \& Larcker, D. F. (1981). Evaluating structural equation models with unobservable variables and measurement error. Journal of Marketing Research, 18(1), 39. https://doi.org/10.2307/31513 12.

Fulford, M., \& Enz, C. A. (1995). The impact of empowerment on service employees. Journal of Managerial Issues, 7(2), 161-175.

Furnham, A., \& Goodstein, L. D. (1997). The organizational climate questionnaire (OCQ). In The 1997 Annual (Vol. 2, pp. 163-179). http://www.wiley.com/WileyCDA/WileyTitle/productCd-08839 04926.html.

Gazzoli, G., Hancer, M., \& Park, Y. (2010). The role and effect of job satisfaction and empowerment on customers' perception of service quality: A study in the restaurant industry. Journal of Hospitality and Tourism Research, 34(1), 56-77. https://doi.org/10.1177/1096348009344235.

George, D., \& Mallery, P. (2003). SPSS for Windows step by step: A simple guide and reference. 11.0 update (4th ed.). Allyn \& Bacon

George, E. (2013). A study on the effect of psychological empowerment of job satisfaction and job related stress among bank employees. Cochin University of Science and Technology.

George, E., \& K.A., Z. (2015). Job related stress and job satisfaction: a comparative study among bank employees. Journal of Management Development, 34(3), 316-329. https://doi.org/10.1108/ JMD-07-2013-0097.

Ghani, N. A. A., Hussin, R., \& Jusoff, K. (2009). Antecedents of psychological empowerment in the Malaysian Private Higher Education Institutions. International Education Studies, 2(3), 161-165.

Gist, M. E. (1987). Self-efficacy: implications for organizational behavior and human resource management. The Academy of Management Review, 12(3), 472-485. https://doi.org/10.2307/258514.

Greasley, K., Bryman, A., Dainty, A., Price, A., Naismith, N., \& Soetanto, R. (2008). Understanding empowerment from an employee perspective: What does it mean and do they want it? Team Performance Management, 14(1-2), 39-55. https://doi.org/10.1108/13527590810860195.

Greasley, K., Bryman, A., Dainty, A., Price, A., Soetanto, R., \& King, N. (2005). Employee perceptions of empowerment. Employee Relations, 27(4), 354-368. https://doi.org/10.1108/014254505106056 97.

Guerrero, S., Chenevert, D., Vandenberghe, C., Tremblay, M., \& Ben Ayed, A. K. (2018). Employees' psychological empowerment and performance: how customer feedback substitutes for leadership. Journal of Services Marketing, 32(7), 868-879. https://doi.org/10.1108/JSM-09-2017-0325.

Hair, J., Black, W., Babin, B. J., Anderson, R., \& Tantham, R. (2006a). Multivariate Data Analysis (6th ed.). Prentice Hal

Hair, J. F., Black, W. C., Babin, B. J., Anderson, R. E., \& Tatham, R. L. (2006b). Multivariate data analysis. In Mathematics of Computation (7th ed., Vol. 50, Issue 181). Pearson Prentice Hall. https:// doi.org/10.2307/2007941

Hair, J. F., Black, W. C., Babin, B. J., \& Anderson, R. E. (2018). Multivariate Data Analysis (8th ed.). Cengage Learning

Hair, J. F., Hult, G. T. M., Ringle, C. M., \& Sarstedt, M. (2014). A primer on partial least squares structural equation modeling (PLS-SEM). In International Journal of Research \& Method in Education (Vol. 38, Issue 2). Sage Publications. https://doi.org/10.1080/1743727x.2015.1005806

Hair, J. F., Hult, G. T. M., Ringle, C. M., \& Sarstedt, M. (2017). A primer on partial least squares structural equation modeling (PLS-SEM) (2nd ed.). Sage.

Hair, J. F. J., Anderson, R. E., Tatham, R. L., \& Black, W. C. (1998). Multivariate Data Analysis (5th ed.). Prentice Hall 
Hair, J. F. J., Black, W. C., Babin, B. J., \& Anderson, R. E. (2009). Structural equation modeling. In Structural Equation Modeling (7th ed.). Prentice Hall. https://doi.org/10.1093/acprof:oso/9780195367621. 001.0001

Hair, J. F., Black, W. C., Babin, B. J. \& Anderson, R. E. (2010). Multivariate data analysis (7th ed.). Pearson.

Hair, J., Howard, M., \& Nitzl, C. (2020). Assessing measurement model quality in PLS-SEM using confirmatory composite analysis. Journal of Business Research, 109, 101-110. https://doi.org/10.1016/j. jbusres.2019.11.069.

Hamidizadeh, M., Baramond, S., \& Latifi, M. (2012). Empowerment and contextual performance with job utility's model. Interdisciplinary Journal of E-Learning and Learning Objects (IJELLO), 3(9), 1199-1218.

Hanaysha, J., \& Tahir, P. R. (2016). Examining the effects of employee empowerment, teamwork, and employee training on job satisfaction. Procedia - Social and Behavioral Sciences, 219, 272-282. https://doi.org/10.1016/j.sbspro.2016.05.016.

Hancer, M., \& George, R. T. (2003). Psychological empowerment of non-supervisory employees working in full-service restaurants. International Journal of Hospitality Management, 22(1), 3-16. https://doi. org/10.1016/S0278-4319(02)00032-4.

Hechanova, M. R. M., Alampay, R. B. A., \& Franco, E. P. (2006). Psychological empowerment, job satisfaction and performance among Filipino service workers. Asian Journal of Social Psychology, 9(1), 72-78. https://doi.org/10.1111/j.1467-839X.2006.00177.x.

Henseler, J., Ringle, C., \& Sinkovics, R. (2009). The use of partial least squares path modeling in international marketing. In Advances in International Marketing (Vol. 20, pp. 277-319). https://doi.org/10. 1108/S1474-7979(2009)0000020014

Hooper, D., Coughlan, J., \& Mullen, M. R. (2008). Structural equation modelling: Guidelines for determining model fit. Electronic Journal of Business Research Methods, 6(1), 53-60. https://doi.org/10. 21427/D79B73.

Hoyle, R. H. (1995). The structural equation modeling approach. basic concepts and fundamental issues. In Hoyle, R. H. (Ed.), Structural Equation Modeling: Concepts, Issues, and Applications (pp. 1-15). Sage Publications,

Hoyle, R. H. (2011). Structural equation modeling for social and personality psychology. Sage Publications. https://doi.org/10.1016/j.encep.2012.03.001

Hu, L., \& Bentler Peter, M. (1999). A study on the effect of psychological empowerment on job satisfaction and job related stress among the bank employees. In Structural Equation Modeling (Vol. 6, Issue 1).

Huang, S., \& Wang, H. (2006). The relationships between the perception of empowerment and its related factors in the nurses. Tzu Chi Nursing Journal, 5(5), 93-104.

Husin, S., Chelladurai, P., \& Musa, G. (2012). HRM Practices, organizational citizenship behaviors, and perceived service quality in golf courses. Journal of Sport Management, 26(2), 143-158. https://doi. org/10.1123/jsm.26.2.143.

Idris, A., See, D., \& Coughlan, P. (2018). Employee empowerment and job satisfaction in urban Malaysia Connecting the dots with context and organizational change management. Journal of Organizational Change Management, 31(3), 697-711. https://doi.org/10.1108/JOCM-04-2017-0155.

Indermun, V., \& Bayat, M. (2013). The Job satisfaction-Employee performance relationship:a theoretical perspective. International Journal of Innovative Research in Management, 11(2), 1-9.

Jha, S. (2011). Influence of psychological empowerment on affective, normative and continuance commitment: A study in the Indian IT industry. Journal of Indian Business Research, 3(4), 263-282. https:// doi.org/10.1108/17554191111180582.

Joo, B. K., \& Lim, T. (2013). Transformational leadership and career satisfaction: the mediating role of psychological empowerment. Journal of Leadership \& Organizational Studies, 20(3), 316-326. https:// doi.org/10.1177/1548051813484359.

Jordan, G., Miglič, G., Todorović, I., \& Marič, M. (2017). Psychological empowerment, job satisfaction and organizational commitment among lecturers in higher education: Comparison of six CEE countries. Organizacija, 50(1), 17-32. https://doi.org/10.1515/orga-2017-0004.

Kanter, R. M. (1983). Frontiers for strategic human resource planning and management. Human Resource Management, 22(1-2), 9-21. https://doi.org/10.1002/hrm.3930220104.

Kazlauskaitè, R., Bučiunienè, I., Turauskas, L., \& Šalčiuviené, L. (2009). A comparative study of employee empowerment in danish and lithuanian hotels. Transformations in Business and Economics, 8(2), 66-85

Kellev, S. W. (1990). Customer orientation of bank employees and culture. International Journal of Bank Marketing, 8(6), 25-29. https://doi.org/10.1108/02652329010004268. 
Kizilos, M. A., Cummings, C., \& Cummings, T. G. (2013). How high-involvement work processes increase organization performance: the role of organizational citizenship behavior. Journal of Applied Behavioral Science, 49(4), 413-436. https://doi.org/10.1177/0021886313479998.

Kline, R. (2005). Principles and practice of structural equation modeling. In Canadian Graduate Journal of Sociology and Criminology (2nd ed., Vol. 1, Issue 1). The Guilford Press. https://doi.org/10.15353/ cgjsc-rcessc.v1i1.25

Kline, R. (2010). Principles and Practice of Structural Equation Modeling. The Guilford Press

Knol, J., \& Van linge, R. (2009). Innovative behaviour: the effect of structural and psychological empowerment on nurses. Journal of Advanced Nursing, 65, 359-370. https://doi.org/10.1111/j.1365-2648. 2008.04876.x.

Kokila, P. (2016). Impact of Employee Empowerment on Job Satisfaction in Banking Sector With Reference To Chennai City. Dr.M.G.R. Educational and Research Institute University

Krog, C. L., \& Govender, K. (2015). The relationship between servant leadership and employee empowerment, commitment, trust and innovative behaviour: A project management perspective. SA Journal of Human Resource Management, 13(1). https://doi.org/10.4102/sajhrm.v13i1.712

Kundu, S. C., Kumar, S., \& Gahlawat, N. (2019). Empowering leadership and job performance: mediating role of psychological empowerment. Management Research Review, 42(5), 605-624. https://doi.org/ 10.1108/MRR-04-2018-0183.

Laschinger, H. K. S. (2008). Effect of empowerment on professional practice environments, work satisfaction, and patient care quality. Journal of Nursing Care Quality, 23(4), 322-330. https://ovidsp.tx. ovid.com/sp-3.31.1b/ovidweb.cgi?WebLinkFrameset=1\&S=INPNFPMIFIDDJGGGNCEKCAJCM IFNAA00\&returnUrl=ovidweb.cgi $\% 253 \mathrm{f} \% 2526 \mathrm{Full} \% 252 \mathrm{bText} \% 253 \mathrm{dL} \% 25257 \mathrm{cS}$. sh. $22.23 \% 25257$ c0\%25257c00001786-200810000-00007\%2526S\%253dINPNFPMIFIDDJGGGNCEKCAJCMI FNAA00\&di.

Laschinger, H. K. S., Finegan, J. E., Shamian, J., \& Wilk, P. (2004). A longitudinal analysis of the impact of workplace empowerment on work satisfaction. Journal of Organizational Behavior, 25(4), 527-545. https://doi.org/10.1002/job.256.

Laschinger, H. K. S., Finegan, J., Shamian, J., \& Wilk, P. (2001). Impact of structural and psychological empowerment on job strain in nursing work settings: Expanding Kanter's model. Journal of Nursing Administration, 31(5), 260-272. https://doi.org/10.1097/00005110-200105000-00006.

Laschinger, H., \& Havens, D. (1996). Staff nurse work empowerment and perceived control over nursing practice, Conditions for work effectiveness. Journal of Nursing Administration, 26(9), 27-35. http:// queens.ezp1.qub.ac.uk/login?url=http://ovidsp.ovid.com/ovidweb.cgi?T=JS\&CSC =Y\&NEWS=N\& PAGE $=$ fulltext $\& D=$ med4\&AN=8816673.

Laschinger, H. K. S., Purdy, N., \& Almost, J. (2007). The impact of leader-member exchange quality, empowerment, and core self-evaluation on nurse manager's job satisfaction. Journal of Nursing Administration, 37(5), 221-229. https://doi.org/10.1097/01.NNA.0000269746.63007.08.

Lautizi, M., Laschinger, H., \& Ravazzolo, S. (2009). Workplace empowerment, job satisfaction and job stress among Italian mental health nurses: An exploratory study. Journal of Nursing Management, 17(4), 446-452. https://doi.org/10.1111/j.1365-2834.2009.00984.x.

Lee, H. M. (2003). The study of the relationship among preschool teacher empowerment, organizational commitment and job satisfaction. Journal of Shu-Te University, 5(2), 69-89.

Letchumanan, T., \& Ramasamy, M. (2017). Factors influence turnover intention in commercial banks malaysia: a theoretical model. Innovative Journal of Business and Management, 6(03), 13-21. https:// doi.org/10.15520/ijbm.vol6.iss3.64.pp13-21.

Likert, R. (1932). A technique for the measurement of attitudes. Archives of Psychology, 140, 1-55

Limbore, N. (2014). Sector in India and overview of performance of Indian banks with reference to net interest margin and market capitalization of banks. A study of banking. Review of Research, 679, $1-11$.

Locke, E. A. (1976). The nature and consequences of job satisfaction. In The handbook of industrial and organizational psychology (Dunnette M, pp. 1297-1349). Rand McNally Inc

Lopes, C., \& Kachalia, D. (2016). Impact of job stress on employee performance in banking sector. Proceedings of the 4th International Conference on Recent Innovations in Science, Engineering and Management, 5(3), 901-913.

Mathieu, J., Gilson, L., \& Ruddy, T. (2006). Empowerment and Team Effectiveness: an empirical test of an integrated model. The Journal of Applied Psychology, 91(1), 97-108. https://doi.org/10.1037/00219010.91.1.97.

Maynard, M., Gilson, L., \& Mathieu, J. (2012). Empowerment-Fad or Fab? A multilevel review of the past two decades of research. Journal of Management, 38, 1231-1281. https://doi.org/10.1177/01492 06312438773 . 
Menon, S. T. (2001). Employee empowerment: An integrative psychological approach. Applied Psychology, 50(1), 153-180. https://doi.org/10.1111/1464-0597.00052.

Murray, W. C., \& Holmes, M. R. (2021). Impacts of employee empowerment and organizational commitment on workforce sustainability. Sustainability (Switzerland), 13, 1-14. https://doi.org/10. $3390 /$ su13063163.

Nelson, B. (2007). Bank of America: Improving Turnover. https://meetingsnet.com/coforatemeetingsince ntives/incentives/best_practices/meetingsbankamericaimproving/

Ning, S., Zhong, H., Libo, W., \& Qiujie, L. (2009). The impact of nurse empowerment on job satisfaction. Journal of Advanced Nursing, 65(12), 2642-2648. https://doi.org/10.1111/j.1365-2648.2009. 05133.x.

Park, J. (2017). How does employee empowerment contribute to higher individual and workgroup performance? An Empirical Assessment of a Trickle-down Model in Law Enforcement Agencies in Ohio. The Ohio State University

Parnell, J. A., \& Crandall, W. (2001). Rethinking participative decision making: A refinement of the propensity for participative decision making scale. Personnel Review, 30(5), 523-535. https://doi. org/10.1108/EUM0000000005937

Patah, M. O. R. A., Radzi, S. M., Abdullah, R., Adzmy, A., Zain, R. A., \& Derani, N. (2009). The influence of psychological empowerment on overall job satisfaction of front office receptionists. International Journal of Business and Management, 4(11), 167-176. https://doi.org/10.5539/ijbm. v4n11p167.

Pelit, E., Öztürk, Y., \& Arslantürk, Y. (2011). The effects of employee empowerment on employee job satisfaction: A study on hotels in Turkey. International Journal of Contemporary Hospitality Management, 23(6), 784-802. https://doi.org/10.1108/09596111111153475.

Perkins, A. (2006). The relationship between social structure and sense of empowerment for school personnel [Michigan state university,U.S.A]. In ProQuest Dissertations and Theses. https://search. proquest.com/dissertations-theses/relationship-between-social-structure-sense/docview/30530 $6870 /$ se-2?accountid $=41849$

Perwej, A. (2020). The impact of pandemic COVID-19 on the Indian Banking System. International Journal of Recent Scientific Research, 11(10), 39873-39883. https://doi.org/10.24327/ijrsr.2020. 1110.5578 .

Preacher, K. J., \& Hayes, A. F. (2004). SPSS and SAS procedures for estimating indirect effects in simple mediation models. Behavior Research Methods, Instruments, and Computers, 36(4), 717-731. https://doi.org/10.3758/BF03206553.

Qing, M., Asif, M., Hussain, A., \& Jameel, A. (2019). Exploring the impact of ethical leadership on job satisfaction and organizational commitment in public sector organizations: the mediating role of psychological empowerment. Review of Managerial Science, 14(6), 1405-1432. https://doi.org/10. 1007/s11846-019-00340-9.

Quin, R. E., \& Spreitzer, G. M. (1997). The road to empowerment: Seven questions every leader should consider. Organizational Dynamics, 26(2), 37-49.

Rafiq, M., \& Ahmed, P. K. (1998). A customer-oriented framework for empowering service employees. Journal of Services Marketing, 12(5), 379-396. https://doi.org/10.1108/08876049810235423.

Rana, S., \& Singh, V. (2016). Employee empowerment and job satisfaction: an empirical study in IT Industry. IOSR Journal of Humanities And Social Science (IOSR-JHSS), 21(10), 23-29.

Randolph, W. A., \& Sashkin, M. (2002). Can organizational empowerment work in multinational settings? Academy of Management Executive, 16(1), 102-115. https://doi.org/10.5465/AME.2002. 6640205.

Raza, H., Mahmood, J., Owais, M., \& Raza, A. (2015). Impact of employee empowerment on job satisfaction of employees in corporate banking sector employees of Pakistan. Journal of Applied Environmental and Biological Sciences, 5(2).

Reidhead, C. (2020). Impact of organizational culture on employee satisfaction: a case of Hilton Hotel, United Kingdom. Journal of Economics and Business, 3(1), https://doi.org/10.31014/aior.1992.03. 01.209

Rhee, J., Seog, S. D., Bozorov, F., \& Dedahanov, A. T. (2017). Organizational structure and employees' innovative behavior: The mediating role of empowerment. Social Behavior and Personality, 45(9), 1523-1536. https://doi.org/10.2224/sbp.6433.

Robbins, T. L., Crino, M. D., \& Fredendall, L. D. (2002). An integrative model of the empowerment process. Human Resource Management Review, 12(3), 419-443. https://doi.org/10.1016/s10534822(02)00068-2.

Rosenberg, M. (1965). Society and the adolescent self-image. In Society and the Adolescent Self-Image. Princeton University Press. https://doi.org/10.2307/2575639 
Saif, N. I., \& Saleh, A. S. (2013). Psychological empowerment and job satisfaction in Jordanian hospitals. International Journal of Humanities and Social Science, 3(16), 250-257.

Saira, Mansoor, S., \& Ali, M. (2021). Transformational leadership and employee outcomes: the mediating role of psychological empowerment. Leadership \& Organization Development Journal, 42(1), 130-143. https://doi.org/10.1108/LODJ-05-2020-0189.

Sarwar, A., \& Khalid, A. (2011). Impact of employee empowerment on employee's job satisfaction and commitment with the organization. Interdiscliplinary Journal of Contemporary Research in Business, $3(2), 664-684$.

Sawyer, J. (1992). Goal and process clarity: specification of multiple constructs of role ambiguity and a structural equation model of their antecedents and consequences. Journal of Applied Psychology, 77, 130-142. https://doi.org/10.1037/0021-9010.77.2.130.

Seibert, S. E., Silver, S. R., \& Randolph, W. A. (2004). Taking empowerment to the next level: a multiple-level model of empowerment, performance, and satisfaction. Academy of Management Journal, 47(3), 332-349. https://doi.org/10.5465/20159585.

Seibert, S. E., Wang, G., \& Courtright, S. H. (2011). Antecedents and consequences of psychological and team empowerment in organizations: a meta-analytic review. Journal of Applied Psychology, 96(5), 981-1003. https://doi.org/10.1037/a0022676.

SLBC. (2015). State Level Bankers Committee Kerala. www.slbckerala.com

Singh, S. K., \& Singh, A. P. (2019). Interplay of organizational justice, psychological empowerment, organizational citizenship behavior, and job satisfaction in the context of circular economy. Management Decision, 57(4), 937-952. https://doi.org/10.1108/MD-09-2018-0966.

Smith, J., Fisher, G., Ryan, L., Clarke, P., House, J., \& Weir, D. (2013). Psychosocial and Lifestyle Questionnaire 2006-2010: Documentation Report Core Section LB (Issue February). The HRS Psychosocial Working Group: Ann Arbor.

Snell, S. A., \& Dean, J. W. (1992). Integrated Manufacturing and Human Resource Management: A Human Capital Perspective. Academy of Management Journal, 35(3), 467-504. https://doi.org/10.5465/ 256484.

Spector, P. E. (1985). Measurement of human service staff satisfaction: Development of the Job Satisfaction Survey. American Journal of Community Psychology, 13(6), 693-713. https://doi.org/10.1007/BF009 29796.

Spence Laschinger, H. K., Finegan, J., \& Shamian, J. (2002). The impact of workplace empowerment, organizational trust on staff nurses' work satisfaction and organizational commitment. Advances in Health Care Management, 3, 59-85. https://doi.org/10.1016/s1474-8231(02)03006-9.

Spreitzer, G. M. (1995). Psychological empowerment in the workplace: dimensions, measurement, and validation. Academy of Management Journal, 38(5), 1442-1465. https://doi.org/10.5465/256865.

Spreitzer, G. M. (1996). Social structural characteristics of psychological empowerment. Academy of Management Journal, 39(2), 483-504. https://doi.org/10.2307/256789.

Spreitzer, G. M. (1992). When organizations dare: The dynamics of psychological empowerment in the workplace. In Dissertation Abstract International (Vol. 53, Issue 11). University of Michigan.

Spreitzer, G. M., Kizilos, M. A., \& Nason, S. W. (1997). A dimensional analysis of the relationship between psychological empowerment and effectiveness, satisfaction, and strain. Journal of Management, 23(5), 679-704. https://doi.org/10.1177/014920639702300504.

Srivastava, A., Bartol, K. M., \& Locke, E. A. (2006). Empowering leadership in management teams: Effects on knowledge sharing, efficacy, and performance. Academy of Management Journal, 49(6), 1239_ 1251. https://doi.org/10.5465/AMJ.2006.23478718.

Stander, M. W., \& Rothmann, S. (2010). Psychological empowerment, job security and employee engagement. South African Journal of Industrial Psychology, 36(1).

Suriadnyana, I. G. (2020). The effect of employee empowerment and work stress on employee organizational commitment mediated by job satisfaction (Case study of financial services cooperatives in Denpasar). Jurnal Ekonomi Dan Bisnis Jagaditha, 7(2), 92-103.

Thomas, K. W., \& Velthouse, B. A. (1990). Cognitive elements of empowerment: an "interpretive" model of intrinsic task motivation. Academy of Management Review, 15(4), 666-681. https://doi.org/10. 5465/amr.1990.4310926.

Turban, F., Kelly Rainer, R., \& Potter, R. E. J., \& (2003). Introduction to information technology. In Information Technology Law Professional Practice Guide. John Wiley and sons. https://doi.org/10.4324/ 9781843145738-4

Vacharakiat, M. (2008). The relationships of empowerment, job satisfaction, and organizational commitment among Filipino and American registered nurses working in the U.S.A. [George Mason University]. https://hdl.handle.net/1920/3363 
Vandenberg, R. J., Richardson, H. A., \& Eastman, L. J. (1999). The impact of high involvement work processes on organizational effectiveness: A second-order latent variable approach. Group and Organization Management, 24(3), 300-339. https://doi.org/10.1177/1059601199243004.

Wagner, J. I. J., Cummings, G., Smith, D. L., Olson, J., Anderson, L., \& Warren, S. (2010). The relationship between structural empowerment and psychological empowerment for nurses: A systematic review. Journal of Nursing Management, 18(4), 448-462. https://doi.org/10.1111/j.1365-2834.2010.01088.x.

Wang, G., \& Lee, P. (2009). Psychological empowerment and job satisfaction. An analysis of interactive effects. Group \& Organization Management - Group Organ Manage, 34(3), 271-296. https://doi.org/ $10.1177 / 1059601108330089$.

Whiting, H. J., Kline, T. J. B., \& Sulsky, L. M. (2008). The performance appraisal congruency scale: An assessment of person-environment fit. International Journal of Productivity and Performance Management, 57(3), 223-236. https://doi.org/10.1108/17410400810857239.

Wong, C. A., \& Laschinger, H. K. S. (2013). Authentic leadership, performance, and job satisfaction: The mediating role of empowerment. Journal of Advanced Nursing, 69(4), 947-959. https://doi.org/10. 1111/j.1365-2648.2012.06089.x.

Yamane, T. (1967). Statistics: An introductory analysis. In The Canadian Journal of Economics and Political Science (2nd ed., Vol. 31, Issue 1). Harper and Row. https://doi.org/10.2307/139661.

Zimmerman, M. A. (1990). Toward a theory of learned hopefulness: A structural model analysis of participation and empowerment. Journal of Research in Personality, 24(1), 71-86.

Zimmerman, M. A. (1995). Psychological empowerment: issues and illustrations. American Journal of Community Psychology, 23(5), 581-599.

Publisher's Note Springer Nature remains neutral with regard to jurisdictional claims in published maps and institutional affiliations. 